\title{
The influence of body mass index on injury pattern in polytrauma: thorax as the main source of complications
}

\author{
Ladislav Mica ${ }^{1 *}$, Catharina Keller ${ }^{2}$, Jindřich Vomela ${ }^{3}$, Marius J. Keel $^{4}$, Otmar Trentz ${ }^{5}$ and Michael Plecko ${ }^{1}$ \\ *Correspondence: ladislav.mica@usz.ch \\ 'Division of Trauma Surgery, University Hospital of Zürich, Switzerland. \\ ${ }^{2}$ Department of Neurology, University Hospital of Cologne, Germany. \\ ${ }^{3}$ Department of Thoracic Surgery, University Hospital of Brno, Czech Republic. \\ ${ }^{4}$ University Hospital of Orthopedic Surgery, Inselspital Bern, Switzerland. \\ ${ }^{5}$ Former Head of the Department of Trauma Surgery, University Hospital of Zürich, Switzerland.
}

\begin{abstract}
Background: Obesity is a growing problem in industrial nations. The aim of this study was to determine the relationship between the body mass index (BMI) and the pattern of injury after polytrauma.

Methods: This retrospective study included 651 patients with an injury severity score (ISS) $\geq 16$ and aged $\geq 16$ years who were subdivided into three groups: BMI $<25 \mathrm{~kg} / \mathrm{m}^{2}$, BMI $25-30 \mathrm{~kg} / \mathrm{m}^{2}$, and BMI $>30 \mathrm{~kg} / \mathrm{m}^{2}$. The Abbreviated Injury Scale (AIS) was used to quantify the injuries in the different anatomical regions. The Murray score was assessed at admission and at its maximum during hospitalization to evaluate pulmonary problems. Data are presented as means \pm standard errors of the means. One way analysis of variance, $\chi^{2}$ test and Kruskal-Wallis test were used for the analyses and the significance level was set at $\mathrm{p}<0.05$.

Results: The AIS of the thorax was $3.2 \pm 0.1$ in the BMI $<25 \mathrm{~kg} / \mathrm{m}^{2}$ group, $3.3 \pm 0.1$ in the BMI $25-30 \mathrm{~kg} / \mathrm{m}^{2}$ group, and $2.8 \pm 0.2$ in the BMI $>30 \mathrm{~kg} / \mathrm{m}^{2}$ group; $\mathrm{p}<0.05$. The Murray score at admission increased significantly with increasing BMI $(0.8 \pm 0.8$ for $\mathrm{BMI}<25 \mathrm{~kg} / \mathrm{m}^{2}, 0.9 \pm 0.9$ for BMI $25-30 \mathrm{~kg} / \mathrm{m}^{2}$, and $1.0 \pm 0.8$ for $\left.0 \mathrm{BMI}>30 \mathrm{~kg} / \mathrm{m}^{2} ; \mathrm{p}<0.05\right)$ as was the maximum Murray score during hospitalization ( $1.2 \pm 0.9$ for BMI $<25 \mathrm{~kg} / \mathrm{m}^{2}, 1.6 \pm 1.0$ for BMI $25-30 \mathrm{~kg} / \mathrm{m}^{2}$, and $1.5 \pm 0.9$ for BMI $\left.>30 \mathrm{~kg} / \mathrm{m}^{2} ; \mathrm{p}<0.001\right)$. The number of ventilator days was also elevated significantly with increasing BMI $\left(5.9 \pm 0.4\right.$ for BMI $<25 \mathrm{~kg} / \mathrm{m}^{2}, 7.7 \pm 0.8$ for BMI $25-30 \mathrm{~kg} / \mathrm{m}^{2}$, and $7.9 \pm 1.6$ for BMI $\left.>30 \mathrm{~kg} / \mathrm{m}^{2} ; \mathrm{p}<0.05\right)$.

Conclusion: Overweight and obesity lead to a higher incidence of thoracic trauma in a polytrauma situation and may additionally handicap ventilation in an obstructive manner.
\end{abstract}

Keywords: BMI, polytrauma, abbreviated injury scale, murray score, SOFA score

\section{Introduction}

Inconsistent findings have been reported for the association between body mass index (BMI) and polytrauma [1,2]. BMI is an anthropometric index defining the weight-to-height relationship, and is expressed as the weight of the individual in kilograms divided by the square of his/her height in meters $\left(\mathrm{kg} / \mathrm{m}^{2}\right)$. Individuals with normal weight have BMls between 18.5 and $24.9 \mathrm{~kg} / \mathrm{m}^{2}$; overweight is defined as $\mathrm{BMI} \geq 25 \mathrm{~kg} / \mathrm{m}^{2}$ and obesity as $B M I \geq 30 \mathrm{~kg} / \mathrm{m}^{2}$. BMI values are age and sex independent [3], and obesity is known to be one of the most significant risk factors for diseases such as cancer, heart disease, and diabetes mellitus in Western countries [4]. The association between chronic diseases and obesity is clear, but the impact of obesity on the pattern of injury after a polytrauma remains unclear [2]. Most studies about the association between BMI and polytrauma have focused on whether obesity and its comorbidities predict the mortality rate in obese patients with polytrauma. Recently, analysis of computational models of injury severity and injury pattern revealed a highly significant association of thoracic and pelvic injuries with increasing BMI [5]. However, this analysis was computed using crash-test dummies in simulated motor vehicle crashes as a standardized trauma mechanism, while some body fat may have a cushioning effect and may protect the abdominal organs from blunt trauma [6]. Older studies have shown that obese patients tend to acquire rib fractures after a trauma, which also highlights the thorax as the weak point in obese people who suffer motor vehicle accidents [7]. It is unknown whether body-fat content plays a role in everyday traumaor may lead to more accidents. In this study scoring systems were used to determine the pulmonary impairment and the overall organ impairment of the patient after a polytrauma. The Murray score depicts explicitly the pulmonary function and the SOFA score mirrors the overall organic function of the polytrauma patient $[8,9]$. The aim of this study was to analyze the association of BMI with the injury pattern and outcomes under polytrauma conditions and to determine whether thoracic injuries should be in the center of interest in overweight and obese patient's after polytrauma indicated by the Abbreviated Injury Scale (AIS), as well asto assess the systemic influence of thoracic problems after a polytrauma by the Murray and SOFA scores.

\section{Patients and methods \\ Patients}

Six hundred fifty-one patients with polytrauma admitted to the emergency room of the University Hospital of Zürich 
Mica et al. Global Epidemic Obesity 2013,

http://www.hoajonline.com/journals/pdf/2052-5966-1-3.pdf

doi: 10.7243/2052-5966-1-3

Table 1. Characteristics of the patient cohort at admission.

\begin{tabular}{|c|c|c|c|c|c|c|c|c|c|}
\hline Characteristics & Total & $\begin{array}{c}\text { BMI 18.5-25 } \\
\mathrm{kg} / \mathrm{m}^{2}\end{array}$ & $\begin{array}{c}\text { BMI 25-30 } \\
\mathrm{kg} / \mathrm{m}^{2}\end{array}$ & $\begin{array}{c}\mathrm{BMI}>30 \mathrm{~kg} / \\
\mathrm{m}^{2}\end{array}$ & p-value & $\begin{array}{l}\text { Kolmogorov- } \\
\text { Smirnov }\end{array}$ & $\begin{array}{c}\text { Bonferroni } \\
\text { BMI 18.5-25 } \\
\text { vs. BMI 25-30 }\end{array}$ & $\begin{array}{c}\text { Bonferroni } \\
\text { BMI 18.5-25 } \\
\text { vs. } \text { BMI > } 30\end{array}$ & $\begin{array}{c}\text { Bonferroni } \\
\text { BMI 25-30 } \\
\text { BMI > 30 }\end{array}$ \\
\hline Patients [N] & 651 & 378 & 224 & 49 & - & - & - & - & - \\
\hline Age [years] & $42.9 \pm 0.75$ & $42.9 \pm 1.0$ & $43.4 \pm 1.3$ & $44.3 \pm 2.4$ & $0.715^{*}$ & 0.001 & ns. & ns. & ns. \\
\hline Sex male/female $[\mathrm{N}]$ & $495 / 156$ & $264 / 114$ & $191 / 33$ & $40 / 9$ & $<0.002^{+}$ & & $<0.001$ & ns. & ns. \\
\hline BMI $\left[\mathrm{kg} / \mathrm{m}^{2}\right]$ & $25.0 \pm 0.1$ & $22.7 \pm 0.1$ & $27.0 \pm 0.1$ & $32.7 \pm 0.6$ & - & - & - & - & - \\
\hline ISS & $28.4 \pm 0.5$ & $28.0 \pm 0.6$ & $29.7 \pm 0.9$ & $25.0 \pm 1.3$ & $0.036^{*}$ & 0.000 & ns.. & ns. & ns. \\
\hline NISS & $38.3 \pm 0.6$ & $37.6 \pm 0.8$ & $39.7 \pm 1.1$ & $37.2 \pm 2.0$ & $0.248^{*}$ & 0.000 & ns. & ns. & ns. \\
\hline APACHE II & $14.6 \pm 0.3$ & $13.9 \pm 0.5$ & $15.8 \pm 0.6$ & $13.6 \pm 1.1$ & $0.026^{*}$ & 0.000 & ns. & ns. & ns. \\
\hline Schock & $1.5 \pm 0.0$ & $1.5 \pm 0.0$ & $1.5 \pm 0.1$ & $1.5 \pm 0.1$ & $0.909^{*}$ & 0.000 & ns. & ns. & ns. \\
\hline GCS & $9.1 \pm 0.2$ & $9.3 \pm 0.3$ & $8.6 \pm 0.4$ & $10.4 \pm 0.8$ & $0.085^{*}$ & 0.000 & ns. & ns. & ns. \\
\hline MAP [mmHg] & $90.7 \pm 1.4$ & $89.5 \pm 1.1$ & $93.2 \pm 3.4$ & $88.8 \pm 2.5$ & $0.427^{\star}$ & 0.000 & ns. & ns. & ns. \\
\hline Hemoglobin $[\mathrm{g} / \mathrm{L}]$ & $11.0 \pm 0.1$ & $11.1 \pm 0.2$ & $11.0 \pm 0.2$ & $11.0 \pm 0.5$ & $0.760^{\ddagger}$ & 0.217 & ns. & ns. & ns. \\
\hline $\begin{array}{l}\text { Base excess } \\
{[\mathrm{mmol} / \mathrm{L}]}\end{array}$ & $-2.9 \pm 0.3$ & $-2.4 \pm 0.4$ & $-3.1 \pm 0.7$ & $-4.1 \pm 0.7$ & $0.129^{\ddagger}$ & 0.168 & ns. & ns. & ns. \\
\hline Lactate $[\mathrm{mmol} / \mathrm{L}]$ & $3.0 \pm 0.1$ & $2.9 \pm 0.1$ & $3.2 \pm 0.2$ & $2.8 \pm 0.2$ & $0.438^{*}$ & 0.000 & ns. & ns. & ns. \\
\hline $\mathrm{pH}$ & $7.3 \pm 0.0$ & $7.3 \pm 0.0$ & $7.3 \pm 0.0$ & $7.3 \pm 0.0$ & $0.774^{*}$ & 0.000 & ns. & ns. & ns. \\
\hline $\begin{array}{l}\text { Prothrombin time } \\
{[\%]}\end{array}$ & $78.6 \pm 1.0$ & $77.9 \pm 1.3$ & $79.1 \pm 1.6$ & $81.2 \pm 3.4$ & $0.073^{*}$ & 0.000 & ns. & ns. & ns. \\
\hline Platelets $\left[10^{3} / \mu \mathrm{L}\right]$ & $196.1 \pm 3.7$ & $196.2 \pm 5.1$ & $192.1 \pm 6.2$ & $214.6 \pm 13.1$ & $0.308^{*}$ & 0.015 & ns. & ns. & ns. \\
\hline
\end{tabular}

in the period 1996-2008 were included in this study. The inclusion criteria were: age $\geq 16$ years and admission within $24 \mathrm{~h}$ of incurring polytrauma, defined as an injury severity score (ISS) $\geq 16$. The patients were treated in the intensive care unit (ICU) and underwent damage control surgery where necessary. The study population was subdivided into three groups (Table 1): BMI $<25 \mathrm{~kg} / \mathrm{m}^{2}, \mathrm{BMI} 25-30 \mathrm{~kg} / \mathrm{m}^{2}$, and $\mathrm{BMI}>30 \mathrm{~kg} / \mathrm{m}^{2}$. The minimum acceptable BMI was 18.5 $\mathrm{kg} / \mathrm{m}^{2}$. All patient data were collected retrospectively from patient records with the approval of the local institutional review board (IRB) according to the University of Zürich IRB guidelines and the World Medical Association Declaration of Helsinki, and the study was conducted according to the guidelines for good clinical practice ("RetrospektiveAnalysen in der ChirurgischenIntensivmedizin" Nr. StV. 01-2008).

\section{Diagnostic protocol}

All hemodynamically stable patients admitted to the trauma bay underwent an immediate whole-body computed tomography (CT) scan. Unstable patients underwent resuscitative procedures according to the Advanced Trauma Life Support ${ }^{\oplus}\left(\right.$ ATLS $\left.^{\oplus}\right)$ standards with a subsequent wholebody $\mathrm{CT}$ scan.

\section{Primary care}

The treatment of all admitted patients was according to the ATLS ${ }^{\circledast}$ guidelines and a previously assessed trauma management protocol after appropriate indications were identified [10,11]. Briefly, after airway intubation, ventilation, and cardiovascular management, lifesaving surgery was performed with decompression of the body cavities, control of any hemorrhage and the identification of any contaminated tissues. These initial surgical interventions were followed by the stabilization of major fractures and the radical debridement of necrotic tissues. Cefazolin was used as the perioperative antibiotic. In all of these patients, enteral nutrition was established within $24 \mathrm{~h}$ of trauma to prevent spontaneous transmigration of the enteric microbial flora and peritoneal contamination.

\section{Scoring systems}

The Murray and SOFA scores were used to evaluate the physiological impairment of the patient $[8,9]$. The Murray score was taken to estimate ventilatory impairment in polytrauma patients focusing as well on the gas exchange as on the functionality of the organ, and the SOFA score was used to assess the overall organ dysfunction in polytrauma patients. The ISS and the New Injury Severity Scale (NISS) were used to define the severity of trauma $[12,13]$. The Acute Physiology and Chronic Health Evaluation (APACHE II) score wasused to evaluate the overall physiological impairment of the patient at admission [14]. The AIS, version 2005, was used to describe injuries in specific anatomical regions.

\section{Laboratory parameters}

Lactate, $\mathrm{pH}$, and hematocrit were measured at regular intervals with a blood gas analyzer (ABL 800 Flex; Radiometer $\mathrm{GmbH}$, Thalwil, Switzerland). Platelets were measured by flow cytometry (FACS-Calibur; Becton Dickinson, Allschwil, Switzerland). The prothrombin time was measured by a standard method described previously [15].

\section{Statistical analysis}

Data are presented as the means \pm standard errors of the 
Mica et al. Global Epidemic Obesity 2013,

http://www.hoajonline.com/journals/pdf/2052-5966-1-3.pdf

doi: $10.7243 / 2052-5966-1-3$

Table 2. Abbreviated Injury Scale.

\begin{tabular}{|c|c|c|c|c|c|c|c|c|c|c|}
\hline $\begin{array}{l}\text { Anatomical } \\
\text { region }\end{array}$ & Total & $\begin{array}{c}\text { BMI 18.5-25 } \\
\mathrm{kg} / \mathrm{m}^{2}\end{array}$ & $\begin{array}{l}\text { BMI 25-30 } \\
\mathrm{kg} / \mathrm{m}^{2}\end{array}$ & $\begin{array}{c}\mathrm{BMI}>30 \\
\mathrm{~kg} / \mathrm{m}^{2}\end{array}$ & p-value & $\begin{array}{l}\text { Kolmogorov- } \\
\text { Smirnov }\end{array}$ & $\begin{array}{l}\text { Bonferroni } \\
\text { BMI 18.5-25 vs. } \\
\text { BMI 25-30 }\end{array}$ & $\begin{array}{c}\text { Bonferroni } \\
\text { BMI 18.5-25 vs. } \\
\text { BMI > 30 }\end{array}$ & $\begin{array}{c}\text { Bonferroni } \\
\text { BMI 25-30 } \\
\text { BMI > 30 }\end{array}$ & $\mathbf{R}^{2}$ \\
\hline AIS head & $3.6 \pm 0.1$ & $3.6 \pm 0.1$ & $3.7 \pm 0.1$ & $3.3 \pm 0.3$ & $0.474^{*}$ & 0.000 & ns. & ns. & ns. & 0.001 \\
\hline AIS face & $2.1 \pm 0.1$ & $2.2 \pm 0.1$ & $2.1 \pm 0.1$ & $1.6 \pm 0.2$ & $0.114^{*}$ & 0.000 & ns. & ns. & ns. & 0.017 \\
\hline AIS thorax & $3.2 \pm 0.0$ & $3.2 \pm 0.1$ & $3.3 \pm 0.1$ & $2.8 \pm 0.2$ & $0.043^{\star}$ & 0.000 & ns. & ns. & 0.039 & 0.002 \\
\hline $\begin{array}{l}\text { AIS } \\
\text { abdomen }\end{array}$ & $4.0 \pm 0.1$ & $4.0 \pm 0.1$ & $4.0 \pm 0.1$ & $3.9 \pm 0.3$ & $0.622^{*}$ & 0.000 & ns. & ns. & ns. & 0.000 \\
\hline AIS spine & $3.0 \pm 0.1$ & $3.1 \pm 0.1$ & $3.0 \pm 0.2$ & $2.3 \pm 0.2$ & $0.093^{*}$ & 0.000 & ns. & ns. & ns. & 0.024 \\
\hline $\begin{array}{l}\text { AIS } \\
\text { extremities }\end{array}$ & $2.8 \pm 0.0$ & $2.8 \pm 0.1$ & $2.7 \pm 0.1$ & $3.0 \pm 0.2$ & $0.176^{*}$ & 0.000 & ns. & ns. & ns. & 0.000 \\
\hline AIS pelvis & $2.8 \pm 0.0$ & $2.7 \pm 0.1$ & $2.9 \pm 0.1$ & $3.0 \pm 0.1$ & $0.196^{\star}$ & 0.000 & ns. & ns. & ns. & 0.021 \\
\hline AIS skin & $1.6 \pm 0.1$ & $1.5 \pm 0.1$ & $1.8 \pm 0.1$ & $1.4 \pm 0.3$ & $0.266^{*}$ & 0.000 & ns. & ns. & ns. & 0.005 \\
\hline
\end{tabular}

Table 3. Laboratory parameters at admission and after $24 \mathrm{~h}$. Data are given as means \pm SEM.

\begin{tabular}{|c|c|c|c|c|c|c|c|c|c|}
\hline Value & Total & $\begin{array}{c}\text { BMI 18.5-25 } \\
\mathrm{kg} / \mathrm{m}^{2}\end{array}$ & BMI $25-30 \mathrm{~kg} / \mathrm{m}^{2}$ & $\begin{array}{c}\mathrm{BMI}>30 \mathrm{~kg} / \\
\mathrm{m}^{2}\end{array}$ & p-value & $\begin{array}{l}\text { Kolmogorov- } \\
\text { Smirnov }\end{array}$ & $\begin{array}{l}\text { Bonferroni } \\
\text { BMI 18.5-25 vs. } \\
\text { BMI 25-30 }\end{array}$ & $\begin{array}{c}\text { Bonferroni } \\
\text { BMI 18.5-25 } \\
\text { vs. } \text { BMI > } 30\end{array}$ & $\begin{array}{c}\text { Bonferroni } \\
\text { BMI 25-30 } \\
\text { BMI > 30 }\end{array}$ \\
\hline $\mathrm{BE}$ at admission $[\mathrm{mmol} / \mathrm{L}]$ & $-2.85 \pm 0.3$ & $-2.4 \pm 0.4$ & $-3.2 \pm 0.7$ & $-4.2 \pm 0.7$ & $0.129^{+}$ & 0.168 & ns. & ns. & ns. \\
\hline $\mathrm{BE}$ after $24 \mathrm{~h}[\mathrm{mmol} / \mathrm{L}]$ & $1.0 \pm 0.3$ & $1.62 \pm 0.3$ & $0.0 \pm 0.5$ & $1.1 \pm 0.5$ & $0.013^{*}$ & 0.028 & 0.010 & ns. & ns. \\
\hline Lactate at admission $[\mathrm{mmol} / \mathrm{L}]$ & $3.0 \pm 0.1$ & $2.9 \pm 0.1$ & $3.2 \pm 0.2$ & $2.8 \pm 0.2$ & $0.438^{*}$ & 0.000 & ns. & ns. & ns. \\
\hline Lactate after $24 \mathrm{~h}[\mathrm{mmol} / \mathrm{L}]$ & $1.6 \pm 0.1$ & $1.4 \pm 0.1$ & $1.8 \pm 0.1$ & $1.7 \pm 0.2$ & $0.015^{\star}$ & 0.000 & 0.015 & ns. & ns. \\
\hline $\mathrm{pH}$ at admission & $7.29 \pm 0.02$ & $7.28 \pm 0.03$ & $7.30 \pm 0.01$ & $7.31 \pm 0.01$ & $0.774^{*}$ & 0.000 & ns. & ns. & ns. \\
\hline $\mathrm{pH}$ after $24 \mathrm{~h}$ & $7.40 \pm 0.00$ & $7.41 \pm 0.00$ & $7.38 \pm 0.01$ & $7.40 \pm 0.01$ & $0.058^{+}$ & 0.105 & ns. & ns. & ns. \\
\hline Prothrombin time atadmission [\%] & $78.6 \pm 0.9$ & $77.9 \pm 1.3$ & $79.1 \pm 1.6$ & $81.2 \pm 3.4$ & $0.601^{*}$ & 0.000 & ns. & ns. & ns. \\
\hline Prothrombin time after $24 \mathrm{~h}$ [\%] & $88.5 \pm 0.6$ & $87.6 \pm 0.8$ & $89.9 \pm 1.0$ & $88.9 \pm 2.3$ & $0.201^{*}$ & 0.000 & ns. & ns. & ns. \\
\hline Platelets at admission $\left[10^{3} / \mathrm{mL}\right]$ & $196.1 \pm 3.7$ & $196.2 \pm 5.0$ & $192.1 \pm 6.2$ & $214.6 \pm 13.1$ & $0.268^{+}$ & 0.090 & ns. & ns. & ns. \\
\hline Platelets after $24 \mathrm{~h}\left[10^{3} / \mathrm{mL}\right]$ & $142.4 \pm 3.3$ & $141.4 \pm 4.7$ & $142.6 \pm 5.2$ & $148.2 \pm 11.4$ & $0.869^{*}$ & 0.001 & ns. & ns. & ns. \\
\hline Hemoglobin at admission $[\mathrm{g} / \mathrm{L}]$ & $11.0 \pm 0.1$ & $11.1 \pm 0.2$ & $11.0 \pm 0.2$ & $10.9 \pm 0.5$ & $0.706^{+}$ & 0.217 & ns. & ns. & ns. \\
\hline Hemoglobin after $24 \mathrm{~h}$ [g/L] & $9.7 \pm 0.1$ & $9.8 \pm 0.1$ & $9.6 \pm 0.2$ & $9.9 \pm 0.5$ & $0.628^{+}$ & 0.282 & ns. & ns. & ns. \\
\hline
\end{tabular}

means (SEM) for continuous variables and as percentages for categorical variables. Kolmogorov-Smirnov test was used for normality testing, if $p<0.05$ the data were considered as normally distributed. The data for the BMI groups were compared using the $\chi^{2}$ test for categorical data and one wayanalysisof variance (ANOVA) for continuous data. Bonferroni correctionused as a post hoc analysisto reduce the witness of a rare event in multiple hypotheses. For not normally distributed data, the Kruskal-Wallis test was used. $p<0.05$ was considered significant. The data were analyzed using SPSS software (version 20.0; IBM, Armonk, NY, USA).

\section{Results}

\section{Patient sample}

All BMI data given below are reported in $\mathrm{kg} / \mathrm{m}^{2}$, but for simplicity of presentation, the units are not included. A total of 651 patients met the inclusion criteria: 378 were of normal weight with a BMI 18.5-25, 224 were overweight, with a BMI 25-30 and 49 were obese with a BMI $>30$. Of these patients, 495 were men and 156 were women, with significantly more men in all three groups ( $p=0.002 ;$ Table 1$)$. The overall mean $\mathrm{BMI}$ was $25.0 \pm 0.1$. The mean age was $42.9 \pm 0.75$ years and did not significantly differ between BMI groups. Only 14 patients (four men and 10 women) met the criteria for being underweight $(\mathrm{BMI}<18.5)$ and were excluded from the study. All patients admitted to the trauma bay who met the inclusion criteria were included in the study.

\section{Injury patterns}

The analysis of the injury patterns according to the AIS revealed significant differences between the BMI groups only in the thorax region, with scores of $3.2 \pm 0.1$ in the BMI 18.5-25 group, $3.3 \pm 0.1$ in the BMI 25-30 group, and $2.8 \pm 0.2$ in the BMI > 30 group ( $p=0.043$; Table 2 ). In this patient sample, ISS and APACHE II values differed between groups, but not NISS $(p=0.036$ and $p=0.026$, Table 1$)$.

\section{Laboratory analysis}

There were significant differences between BMI groups in lactate ( $p=0.015) 24 \mathrm{~h}$ after admission, but these values were still within the normal range (Table 3 ). Base excess (BE), prothrombin time, platelet values and hemoglobin did not differ significantly between BMI groups at any time point (Table 3).

\section{Outcome measurement}

Overall, $17.5 \%$ of all patients included in the study died: $15.1 \%$ of the BMI $18.5-25$ group; $21.0 \%$ of the BMI 25-30 group; and 
Mica et al. Global Epidemic Obesity 2013,

http://www.hoajonline.com/journals/pdf/2052-5966-1-3.pdf

doi: $10.7243 / 2052-5966-1-3$

Table 4. Outcome values for the entire patient cohort, showing Murray and SOFA scores at admission, their maximal values (max.) during hospitalization and the days after admission at which the maximal values were reached (day max.). Data are given as means \pm SEM, ${ }^{\star} \chi^{2}$.

\begin{tabular}{|c|c|c|c|c|c|c|c|c|c|}
\hline Outcome & Total & $\begin{array}{c}\text { BMI 18.5-25 } \\
\mathrm{kg} / \mathrm{m}^{2}\end{array}$ & BMI $25-30 \mathrm{~kg} / \mathrm{m}^{2}$ & $\mathrm{BMI}>30 \mathrm{~kg} / \mathrm{m}^{2}$ & p-value & $\begin{array}{l}\text { Kolmogorov- } \\
\text { Smirnov }\end{array}$ & $\begin{array}{l}\text { Bonferroni } \\
\text { BMI 18.5-25 vs. } \\
\text { BMI 25-30 }\end{array}$ & $\begin{array}{c}\text { Bonferroni } \\
\text { BMI 18.5-25 } \\
\text { vs. } \text { BMI > } 30\end{array}$ & $\begin{array}{c}\text { Bonferroni } \\
\text { BMI 25-30 } \\
\text { vs. } \text { BMI > } 30\end{array}$ \\
\hline Death [N, (\%)] & $114(17.5 \%)$ & $57(15.1 \%)$ & $47(21.0 \%)$ & $10(20.4 \%)$ & $0.181^{*}$ & 0.000 & - & - & - \\
\hline Day of death [d] & $4.7 \pm 1.3$ & $4.5 \pm 1.8$ & $5.7 \pm 2.3$ & $2.7 \pm 1.7$ & $0.765^{\dagger}$ & 0.000 & ns. & ns. & ns. \\
\hline Hospitalization [d] & $25.8 \pm 1.1$ & $24.1 \pm 1.2$ & $27.7 \pm 2.5$ & $29.2 \pm 3.6$ & $0.228^{\dagger}$ & 0.000 & ns. & ns. & ns. \\
\hline Intensive care stay [d] & $11.6 \pm 0.5$ & $10.7 \pm 0.6$ & $12.6 \pm 0.9$ & $13.1 \pm 2.2$ & $0.164^{\dagger}$ & 0.000 & ns. & ns. & ns. \\
\hline Ventilation [d] & $6.7 \pm 0.4$ & $5.9 \pm 0.4$ & $7.7 \pm 0.8$ & $7.9 \pm 1.6$ & $0.044^{\dagger}$ & 0.000 & ns. & ns. & ns. \\
\hline Murray score (admission) & $0.9 \pm 0.0$ & $0.8 \pm 0.0$ & $0.9 \pm 0.1$ & $1.0 \pm 0.1$ & $0.043^{\dagger}$ & 0.000 & ns. & ns. & ns. \\
\hline Murray score (max.) & $1.4 \pm 0.0$ & $1.2 \pm 0.0$ & $1.6 \pm 0.1$ & $1.5 \pm 0.1$ & $0.000^{\dagger}$ & 0.000 & 0.000 & ns. & ns. \\
\hline Murray score (day max.) [n] & $2.8 \pm 0.2$ & $2.6 \pm 0.2$ & $3.3 \pm 0.3$ & $3.0 \pm 0.6$ & $0.113^{\dagger}$ & 0.000 & ns. & ns. & ns. \\
\hline SOFA (admission) & $6.1 \pm 0.2$ & $5.9 \pm 0.2$ & $6.2 \pm 0.3$ & $6.5 \pm 0.6$ & $0.517^{\dagger}$ & 0.000 & ns. & ns. & ns. \\
\hline SOFA (max.) & $7.6 \pm 0.2$ & $7.1 \pm 0.2$ & $8.2 \pm 0.3$ & $7.9 \pm 0.6$ & $0.017^{\dagger}$ & 0.000 & 0.018 & ns. & ns. \\
\hline SOFA (day max.) [n] & $2.1 \pm 0.1$ & $1.9 \pm 0.2$ & $2.5 \pm 0.3$ & $1.9 \pm 0.4$ & $0.087^{\dagger}$ & 0.000 & ns. & ns. & ns. \\
\hline
\end{tabular}

$20.4 \%$ of the $\mathrm{BMI}>30$ group $(p=0.181$; Table 4$)$. The number of days on the ventilator in ICU increased with increasing BMI: the average number of ventilator days for all patients was $6.7 \pm 0.4 \mathrm{~d}$, tendencially increasing according the BMI group (Table 4). Pulmonary assessment by the Murray score at admission showed increasing tendencies according the BMI groups (Table 4). The overall maximal Murray score value reached 1.4 $\pm 0.9: 1.2 \pm 0.9$ for the BMI 18.5-25 group; $1.6 \pm$ 1.0 for the BMI 25-30 group; and $1.5 \pm 0.9$ for the BMI $>30$ group ( $p<0.001 ;$ Table 4$)$. There were no significant differences between the groups in the SOFA score at admission; however, the maximal value was significantly elevated in the overweight group. The overall maximal value was $7.6 \pm 4.5: 7.1 \pm 4.3$ for the BMI 18.5-25 group; $8.2 \pm 4.8$ for the BMI 25-30 group; and $7.9 \pm 4.5$ for the BMI $>30$ group ( $p=0.017$; Table 4 ).

\section{Discussion}

This study was designed to evaluate the impact of BMI on the pattern of injury in patients with polytrauma. Understanding the main source of complications in overweight and obese polytrauma patients may play a pivotal role in their multidisciplinary treatment. In Western societies, the prevalence of obesity is a growing problem that appears to be altering current medical and surgical treatment strategies [16]. Overweight patients have significantly more comorbidities than normal weight patients and face more posttraumatic complications $[17,18]$.

The overweight patient exhibits more non-muscle mass than the normal weight patient; this cannot be controlled during an accident resulting in a greater 'momentum effect' and leading to a higher deceleration [19]. The cushioning effect of fat might be a satisfactory explanation for fewer injuries in obese patients after blunt abdominal trauma, but this would not apply to the thoracic region [19]. Because of a higher kinetic energy during an accident, the overweight or obese patient sustains a higher impact than the normal weight patient, which leads to a higher incidence of thoracic injuries among these patients. However, in this study, the AIS for thorax was lowest in the obese group, so that above a certain BMI, a cushion effect must be postulated [19]. Measurements of pulmonary parameters reported as a Murray score at admission and at the maximum during hospitalization showed a significant increase with increasing BMI [10]. This problem may be explained not only by the trauma, but might also be related to body-fat content: overweight and obese patients may have obstructed breathing, formerly called Pickwickian Syndrome, which is reflected in the Murray score [20]. The low efficacy of respiration in overweight and obese patients leads to higher maximal values of the Murray score during hospitalization (Table 4). Interestingly, this impaired respiration significantly affects the $\mathrm{BE}$, lactate and $\mathrm{pH}$, as there were significant differences between BMI groups after the first $24 \mathrm{~h}$ (Table 3); however, these parameters were still within physiological ranges. It could be postulated that this is the product of renal compensation, but fluid treatment in the ICU is a more obvious cause. The number of ventilator days increased with increasing BMl: obese patients had significantly more ventilator days even though the AIS was lowest in the obese group. Again, it seems that it is the obstructive breathing of obese patients, not only the trauma itself, that is the primary reason why obese patients spent more time on a ventilator; weaning from the ventilator is always prolonged in patients with obstructive breathing disorders. The maximum SOFA score was also increased significantly in overweight and obese patients, but not the score at admission, which also reflects the respiratory problems of the overweight and obese patients.However, the compliance of the lung used in both scoring systems may mainly contribute to the significance of the maximal values of the SOFA score, on the one hand. On the other hand the just significant difference of the Murray score at admission may reflect only ventilator problems and not severe traumatic problems as reflected by 
the AIS for the thorax. In such early stages after a polytrauma there is no change in compliance of the lung or chest x-ray with respect to the obtained AIS of the thorax. Only the PEEP and oxygenation values are left to explain the differences of the Murray score at admission. This may be explained by the obstructive component of the fatty tissue as mentioned above, the Pickwickian Syndrome in some extent. Secondarily, probably caused by the decreased oxygenation the other organ parameters may change in an adverse manner leading to significant differences in the maximal values of the SOFA score. Whether the significantly elevated mortality of the overweight patients after suffering a polytrauma is founded in their respiratory difficulties or in other thoracic problems needs further investigation. The limitations of this study are determined by the study's retrospective character. The conclusions made here are interpretations of probabilities and no casualties. This study is strongly limited to Western Europe and cannot be transferred to other geographical and cultural regions.

\section{Conclusion}

In summary, this study showed that compared with normal weight patients, overweight patients have a higher incidence of thoracic trauma, but obese patients have a lower incidence of thoracic trauma, probably because of the cushioning effect of body fat [19]. However, excess fatty tissue leads to obstructed ventilation, resulting in higher Murray scores and higher numbers of ventilator daysand secondarily probably to increased SOFA score, probably by a decreased oxygen supply of the organs. The awareness of thoracic problems in overweight and obese polytrauma patients under ICU conditions may lead to an optimization of ventilator parameters that will probably improve their outcomes.

\section{Competing interests}

The authors declare that they have no competing interests.

\section{Authors' contributions}

Study design, statistical analysis, preparing of the Manuscript and collection of the data was performed by L. Mica. Acquisition of the data was performed by C. Keller, J. Vomela, M. Keel, O. Tretz and M. Plecko.

\section{Publication history}

Editor: Alexander D. Miras, Medical Research Council, UK. Received: 03-Mar-2013 First Revised: 29-Mar-2013 Final Revised: 22-May-2013 Accepted: 24-May-2013 Published: 28-May-2013

\section{References}

1. Maheshwari R, Mack CD, Kaufman RP, Francis DO, Bulger EM, Nork SE and Henley MB: Severity of injury and outcomes among obese trauma patients with fractures of the femur and tibia: a crash injury research and engineering network study. $J$ Orthop Trauma 2009, 23:634-9. | Article | PubMed

2. Neville AL, Brown CV, Weng J, Demetriades D and Velmahos GC: Obesity is an independent risk factor of mortality in severely injured blunt trauma patients. Arch Surg 2004, 139:983-7. |
Article | PubMed

3. World Health Organization (WHO): Global Database on Body Mass Index.. I Website

4. Calle EE, Thun MJ, Petrelli JM, Rodriguez C and Heath CW, Jr.: Body-mass index and mortality in a prospective cohort of U.S. adults. N Engl J Med 1999, 341:1097-105. I Article I PubMed

5. Kim JE, Kim IH, Shum PC, Shih AM, Pintar F, Shen W, Ma X, Laud PW, Heymsfield SB, Allison DB and Zhu S: A computational study of injury severity and pattern sustained by overweight drivers in frontal motor vehicle crashes. Comput Methods Biomech Biomed Engin 2012. I Article I PubMed

6. Arbabi S, Wahl WL, Hemmila MR, Kohoyda-Inglis C, Taheri PA and Wang SC: The cushion effect. J Trauma 2003, 54:1090-3. I Article I PubMed

7. Boulanger BR, Milzman D, Mitchell K and Rodriguez A: Body habitus as a predictor of injury pattern after blunt trauma. $J$ Trauma 1992, 33:228-32. | Article | PubMed

8. Murray JF, Matthay MA, Luce JM and Flick MR: An expanded definition of the adult respiratory distress syndrome. Am Rev Respir Dis 1988, 138:720-3. | Article I PubMed

9. Marshall JC, Cook DJ, Christou NV, Bernard GR, Sprung CL and Sibbald WJ: Multiple organ dysfunction score: a reliable descriptor of a complex clinical outcome. Crit Care Med 1995, 23:1638-52. | Article | PubMed

10. Ertel W, Trentz O: Causes of shock in the severely traumatized patient: emergency treatment. In: Goris RJA, Trentz O (Eds). The Integrated Approach to Trauma Care: The First 24 Hours. Springer: Berlin, Germany, 1995, 78-87. I Book

11. Trentz O, Friedl HP: Therapeutic sequences in the acute period in unstable patients. In: Goris RJA, Trentz O (Eds).The Integrated Approach to Trauma Care: The First 24 Hours. Springer: Berlin, Germany, 1995, 172-8. I Book

12. Baker SP, O'Neill B, Haddon W, Jr. and Long WB: The injury severity score: a method for describing patients with multiple injuries and evaluating emergency care. J Trauma 1974, 14:187-96. | Article | PubMed

13. Champion HR, Copes WS, Sacco WJ, Lawnick MM, Bain LW, Gann DS, Gennarelli T, Mackenzie E and Schwaitzberg S: A new characterization of injury severity. J Trauma 1990, 30:539-45. | Article I PubMed

14. Knaus WA, Draper EA, Wagner DP and Zimmerman JE: APACHE II: a severity of disease classification system. Crit Care Med 1985, 13:818-29. I Article I PubMed

15. Jackson CM, White GC, 2nd, Barrowcliffe T, Esnouf MP, Jespersen J, Kluft C and Lenahan J: A reference system approach to future standardization of laboratory tests for hemostasis. A position paper of the Joint Committee of the IFCC Scientific Division and the ISTH Scientific and Standardization Committee. Thromb Haemost 2002, 87:165-9. | PubMed

16. Quesenberry CP, Jr., Caan B and Jacobson A: Obesity, health services use, and health care costs among members of a health maintenance organization. Arch Intern Med 1998, 158:466-72. | Article | PubMed

17. Hoffmann $M$, Lefering $R$, Gruber-Rathmann $M$, Rueger JM and Lehmann W: The impact of BMI on polytrauma outcome. Injury 2012, 43:184-8. | Article | PubMed

18. Brown CV, Neville AL, Rhee P, Salim A, Velmahos GC and Demetriades D: The impact of obesity on the outcomes of 1,153 critically injured blunt trauma patients. J Trauma 2005, 59:1048-51. | Article | PubMed 
Mica et al. Global Epidemic Obesity 2013,

http://www.hoajonline.com/journals/pdf/2052-5966-1-3.pdf

19. Kent RW, Forman JL and Bostrom O: Is there really a "cushion effect"?: a biomechanical investigation of crash injury mechanisms in the obese. Obesity (Silver Spring) 2010, 18:74953. | Article | PubMed

20. Bickelmann AG, Burwell CS, Robin ED and Whaley RD: Extreme obesity associated with alveolar hypoventilation; a Pickwickian syndrome. Am J Med 1956, 21:811-8. | Article | PubMed

\section{Citation:}

Mica L, Keller C, Vomela J, Keel M J, Trentz O and Plecko M: The influence of body mass index on injury pattern in polytrauma: thorax as the main source of complications. Global Epidemic Obesity 2013, 1:3. http://dx.doi.org/10.7243/2052-5966-1-3 